Review

\title{
Water reuse in the food industry
}

\author{
R. L. Bailone ${ }^{1,2} \cdot$ R. C. Borra ${ }^{2}$ H. C. S. Fukushima ${ }^{3}$ L. K. Aguiar ${ }^{4}$
}

Received: 1 November 2021 / Accepted: 7 December 2021

Published online: 10 January 2022

(c) The Author(s) 2022 OPEN

\begin{abstract}
Due to the significant growing demand for water, it is urgent to those in the food industry to consider a more rational and sustainable use of such a scarce natural resource. This chapter highlights alternative food processing methods that contemplate recycling and reusing water. Based on a systematic literature review, it highlights the adoption of cleaner production methods. The chapter focus on the meat and fresh produce sectors where evidence shows that water sustainability related methods is the most needed. Suggestions are proposed to minimize water waste through the treatment of effluents and decrease the impact of effluent pollution on the environment. In so doing, clear environmental and economic benefits could be achieved through the reduction of costs and value-adding to the final product. Yet, the implementation of Cleaner Production Methods would require support from the industry, policymakers, and consumers to encourage the recycling and reuse of water.
\end{abstract}

\section{Introduction}

Food chains are complex systems of resource-intensive operations which require varied sets of skills and factors of production such as technology, labor, logistics, financial and natural capital [40]. According to Toussaint et al. [104], there are currently pressures affecting the social, economic, and environmental dimensions of food production and consumption imply that a wide range of stakeholders has to address the increased awareness and needs of populations to meet global food demand. In light of this, the sustainable use of natural water resources is of great relevance for food processing industries. This is because to bring food from farms to the consumers' tables would require a great quantity of water. For many food commodities that we daily depend on, it has been estimated that about $70 \%$ of the total water used would have already been spent just to produce it at farm level [58]. Thus, considering the future water needs to only meet the population demand estimated to reach 10 billion people by 2050, the International Union for the Conservation of Nature (IUCN) has forecat an increase of 55-60\% in demand for water [60].

It is known that in the calculations of the overall water's ecological footprint in order to produce good quality water it is necessary to collect, transport and treat the liquid. In the process there is a great egergy requirment regarding the building of water treatment stations, the laying down of pipelines, the housig of equipment, the use of chemical cleaning products and labor. As a result of the water treatment, waste is also produced in the form of sludge which can be a polluting element if left untreated [74, 93]. Despite the relatively low cost of water in many countries, it is expected that

R. L. Bailone, ricardo.bailone@agricultura.gov.br | ${ }^{1}$ Federal Inspection Service of Ministry of Agriculture, Livestock and Supply of Brazil, Washington Luiz Road, km 237, São Carlos-SP 13565-905, Brazil. ²Department of Genetic and Evolution, Federal University of São Carlos, São Carlos-SP, Brazil. ${ }^{3}$ Center of Biological and Health Sciences, Federal University of São Carlos, São Carlos-SP, Brazil. ${ }^{4}$ Department of Food, Land and Agribusiness Management, Harper Adams University, Newport, UK. 
the many activities involved in bringing water from its point of abstraction, through treatment and distribution, until it is returned to nature it will be considerably costly in the future.

Increasingly, natural water sources such as groundwater, rivers, and lakes have become compromised regarding its quality and safety due to chemical and or microorganism contamination. Therefore, it is not difficult to realise that water has becomes a precious natural and renewable resource which would require careful management [57]. Due to climate change and environmental degradation, future routine practices in the food industry which might be currently taken for granted could be seriously affected by the ever-increasing water scarcity. This is because, a great volume of water is used during cleaning and hygiene process either for personal or food manufacturing daily routines. In the food industry, many operational practices involve the use of water. For example, staff must keep high standards of personal hygiene such as washing hands, showering, disinfecting shoes, laundering, and sanitation. At the end of a production batch, installations and equipment require to be cleaned and sanitized. In many of these aforementioned practices would demand the use of water. Yet, adopting practices that consider alternative food processing methods that cater for the recycling and reusing of water [10] is a must. Moreover, water-saving strategies can also bring both environmental and financial benefits to businesses. On the one hand, resource-saving practices are reflected in long term cost reduction practices [2]. Moreover, consumer pressure on the sustainability of food production has also been forcing manufacturers to adopt a more sustainable approach to production. In turn, food manufacturers have started to consider long-term water sustainability measures which, on the other hand, also strengthen their marketing relationship strategies.

Therefore, this chapter aims to highlight the importance of more sustainable use of water to those involved in the food industry as well as students and consumers in general. Owed to the enormity of the problem, this chapter will only focus on the use of water use during the stages of food processing. Furthermore, also due to the food industry being characterized by a diverse range of sectors or categories such as fresh produce (fruit and vegetable), grains (milling and bakery; dairy; meat; fishery, beverages, confectionery, amongst others [27], it would be essential to further constrain the focus of the topics covered in this chapter on activities at the food processing level where raw materials are transformed into various products. However, there would be occasions during which broader agricultural and livestock raw materials products would be mentioned.

Through the measures presented in this chapter, food and beverage processing industries could develop short and long-term strategic plans for more sustainable water use management, thus contributing to the reduction of environmental impacts, reducing costs, and adding value to the final product. This is possible when Cleaner Production Methods (CPM) is adopted. CPM is a concept proposed by United Nations which aims to prevent, contain, and minimize the detrimental impact industrial activity could cause on the environment and consequently on society. Through the elaboration of economic and environmental strategies applied continuously, CPM promotes the minimization of losses of natural resources, as well as a lower emission of pollutants to the environment, increasing the competitiveness of the industry by reducing costs and adding value $[35,83,89]$. A reduced use of water can take place by mainly changing processes along the production line. In so doing, cleaner production practices would help reduce water consumption during, for example, slaughter and meat processing, and fresh produce handling in general. That would avoid or remedy the detrimental environmental and health impact it might have due to the high water loads needed. Therefore, managers and technicians need to address the increasing challenges to access and manage new and clean water resources. They must also continuously look for strategies that reduce operating costs and set money-saving goals and strategies.

\section{Stipulation of goals}

Food companies have to adhere to Hazard Analysis and Critical Control Points (HACCP), a food risk and hazard control program. A HACCP plan aims to identify irregularities along the process stages that fall outside the acceptable limits and tolerances to correct them as soon as possible. The plan is divided into five basic principles, which are: identifying the hazard during the process, determining critical points of control and its required limits of acceptance, monitoring the proceedings, and applying corrective measures when necessary, that is when production deviations occur [62]. Elaborating and implementing HACCP plans for water reuse can enable management to identify areas of improvement within the manufacturing process [57] and should, of course, consider safety hazards and risks [23]. Therefore, a HACCP Action Plan would allow better control of the use of the water network and an indication of processes to ensure efficient water management. The plan must be based on a company's ability to verify, self-monitor, and control its practices to ensure the implementation, monitoring, corrective actions, and checks of the program regularly. 
Benchmarking, as defined by the International Water Association (IWA), is searching for the best management practices in a given industry, leading to superior performance. Therefore, based on the current literature, we have identified some key benchmark figures for water consumption in the food industry according to various food products (Table 1).

The guidelines on the reuse of water serves as a target for managers monitoring and implementation of the likely reduction in water use and wastewater. Water reuse practices in the food industry present a significant challenge in the coming years for both companies and public health authorities regarding knowledge, technical expertise, and documentation. After the initial systematic search of the literature was conducted, the EU Directive 2020/2184 ruling on water quality intended for human consumption was published. The EU Directive 2020/2184 provides for... "food business operators that have their own water source and use it for the specific purposes of their business should be able to be exempted from this Directive provided that they comply with relevant obligations, in particular regarding hazard analysis and critical control point principles and remedial actions under relevant Union legislation on food. Food business operators that have their own water source and act as water suppliers should comply with this Directive in the same way as any other water supplier" SPS:refid::bib39[39]. Therefore, some of the guidelines are broad to cater for many different situations.

After this introduction, an analysis of the water needs for specific food commodities such as fresh produce and livestock will be analyzed. Some of the principles behind the methods that will be addressed in this chapter could be applicable to the actual establishment in many different countries with some adjustments.

Table 1 Benchmarks of wastewater per production of different food products

\begin{tabular}{|c|c|c|c|}
\hline & Product & Water used inside the industry & References \\
\hline \multirow[t]{3}{*}{ Beverage } & Soft drink & 3-L/L soft drink & Gumbo et al. [51] \\
\hline & \multirow[t]{2}{*}{ Beer } & $2.5-6.4 \mathrm{hl} / \mathrm{hl}$ beer & The Brewers of Europa [21] \\
\hline & & $3.5-10 \mathrm{hl} / \mathrm{hl}$ beer & Valta et al. [114] \\
\hline Fruits and vegetables & Olive oil & $0.25-1.24 \mathrm{~L} / \mathrm{kg}$ olive oil & Valta et al. [114] \\
\hline \multirow[t]{28}{*}{ Animal products } & \multirow[t]{3}{*}{ Milk } & 1.5-5 L/L milk & Riera et al. [91] \\
\hline & & $0.6-1.8 \mathrm{~L} / \mathrm{L}$ milk & Environment Agency [36] \\
\hline & & 1.2-3.4 L/L milk & Vourch et al. [115] \\
\hline & Cheese & 1-4L/L processed milk & Valta et al. [114] \\
\hline & Milk powder & $0.8-1.7 \mathrm{~L} / \mathrm{L}$ milk & Environment Agency [36] \\
\hline & Ice-cream & 4-5 L/kg ice-cream & Environment Agency [36] \\
\hline & \multirow[t]{6}{*}{ Pig } & $1.5-10 \mathrm{~L} / \mathrm{kg}$ & Valta et al. [114] \\
\hline & & $160-230 \mathrm{~L} /$ pig & Environment Agency [37] \\
\hline & & 400-1500 L/pig & Cetesb [25] \\
\hline & & 180-300 L/pig & Unep [106] \\
\hline & & 373-500 L/pig & CPTS $[29,30]$ \\
\hline & & $160-230 \mathrm{~L} / \mathrm{pig}$ & Environment Agency [37] \\
\hline & \multirow[t]{6}{*}{ Cattle } & $2.5-40 \mathrm{~L} / \mathrm{kg}$ & Valta et al. [114] \\
\hline & & 700-1000 L/animal & Environment Agency [37] \\
\hline & & 1000-3000 L/animal & Cetesb [25] \\
\hline & & 800-1800 L/animal & Unep [106] \\
\hline & & 973-2800 L/animal & CPTS $[29,30]$ \\
\hline & & 700-1000 L/animal & Environment Agency [37] \\
\hline & \multirow[t]{2}{*}{ Sheep/goat } & 300 L/animal & Rio Grande do Sul [92] \\
\hline & & 100-250 L/animal & Environment Agency [37] \\
\hline & \multirow[t]{6}{*}{ Poultry } & $6-30 \mathrm{~L} / \mathrm{kg}$ & Valta et al. [114] \\
\hline & & $30 \mathrm{~L} / \mathrm{bird}$ & Aguiar and Caleman [2] \\
\hline & & 17-24 L/bird & Unfried and Yoshi [107] \\
\hline & & 16.9 L/bird & Matsumura and Mierzwa [76] \\
\hline & & 8-15 L/bird & Environment Agency [38] \\
\hline & & $16.3 \mathrm{~L} / \mathrm{kg}$ & Oliveira and Bellaver [82] \\
\hline & Turkey & 40-60 L/bird & Environment Agency [38] \\
\hline & Fish & $14.98 \mathrm{~L} / \mathrm{kg}$ & Napoli [80] \\
\hline
\end{tabular}

Source: adapted from Bailone et al. [10] 


\section{Fruit and vegetables}

Especially in the fresh produce sector, water is required to clean fruit and vegetables to remove dirt from the fields. The use of water in the initial stages of post-harvest is relevant since the produce could be chemically treated to combat pests such as insects and microorganisms [48]. Consequently, washing inbound produce consumes a significant amount of freshwater upon arrival. The volume of water needed is considerable because an aqueous medium also serves for different purposes. As washing is carried out, the segregation of good fruit from other material thath is either too heavy or too light take place. An aqueous medium also allows the product to be moved from one postharvest processing stage to another within a packhouse. Moving produce in water has its advantages, and it is a common practice when handling fruit and tubers. For example, potatoes being processed for frozen French fries, and apples are two good examples of water application in a packing house. Moving produce between washing, sorting, and grading using an aqueous medium reduces the change of bruising, which would be detrimental to produce quality and shelflife [103].

Furthermore, water is still required in the packing house to maintain a high air relative humidity during chilling or, conversely, for blanching. For the initial stages of washing produce arriving from the fields, water reuse by reducing the frequency of the need to change of spent water is adequate. In stages further down the processing of fresh produce, adjusting the dose of chemicals used for sanitizing or even using other methods such as Ultraviolet (UV) treatment can be a cost-effective alternative. Yet, the minimally processed product approach allows fruit and vegetables to be ready for consumption. Hence, by following a set of pre-established hygiene and sanitation conditions, minimally processed fresh produce maintains the organoleptic characteristics of the food [16]. There is, nonetheless, an expectation that minimally processed would also provide water-saving solutions.

\section{Beverages}

In recent decades, complying with a more sustainable method of food production and processing has become one of the most critical challenges for the beverage industry. Aguiar and Caleman [2] posited that food manufacturers had been the key drivers of sustainability until that moment in time. Their actions were decisive in "enabling transformations in business practices that would enable them to attain higher levels of sustainability gains." They also argued that food manufacturers, by acting "as spearheads" in sustainability, had an advantage over those who did not. It is known that many food manufacturers have corrected many inefficiencies and introduced saving practices in, for example, energy, heat, water, and raw materials waste. That has resulted in food manufacturers benefiting from reducing their operational costs and positioning themselves in the consumers' minds for being 'sustainable'. As a result, food manufacturers directly satisfied both consumers' pressures and pro-environmental consumers' groups at the same time.

Nonetheless, for the food manufacturers, the largest cost-redcution advantage has been in enabling them to accrue higher margins and return increased profits [2] to shareholders. Therefore, it is not surprising that more and more food processors have been implementing measures to improve their environmental, social, or economic sustainability credentials at various production processes. The pressure on the part of consumers on food manufacturers has also been growing, forcing the industry to adapt to new production methods. Consumers are not exclusively price and intrinsic quality-oriented but expect a bundle of benefits from their purchase. Therefore, consumption is complex as consumer behavior can be split between, on the one hand, satisfying personal needs and desires and, on the other hand, pro-environmental altruism and societal compliance [94].

The beverage sector is particularly responsible for manufacturing a range of products from alcoholic (winery, vinasses, molasses, beer, and spirits) to non-alcoholic (fruit juices, vegetable juice, mineral water, sparkling water, flavored water, and soft drinks) beverages [53]. The manufacturing of drinks requires a significant quantity of fresh water, which, in turn, generates considerable amounts of wastewater at different stages of processing. These include the liquid part of the drink itself, water used as a cooling agent, washing and disinfecting bottles, cleaning the work areas, washing the floors, and during washdown [51].

In beverage production, hygiene and sanitation standards should be kept high all the time. Therefore, microbiological control as part of a HACCP plan foresees that water treated with acidic solutions should be used as one of the 
microbial hurdles [53]. Nonetheless, water reuse and treatment could save the drinks' manufacturer from the burden of abstracting more fresh, natural water. It is, thus, recommended that the beverage/soft drink industry wastewater is treated through a combination of Reverse Osmosis and Ion Exchange, which would be suitable for being reused in bottle washing plants and boilers. Furthermore, Haroon et al. [53] proposed that dilution of wastewater with fresh water up to $50 \%$ could be reused for the first three bottle-washing stages.

Up to the widespread use of plastic in bottling, the reuse of glass bottles was responsible for a great deal of freshwater wastage. That was required because of washing and sanitation, rinsing to remove trace elements of chemical agents before the bottles being refilled. Many chemical agents used in bottling sanitization can include chlorine, sodium hydroxide, and detergents. Water is used extensively in bottle cleaning and sanitation but these activities are also large contributors of waste $[53,57]$. Yet, some advocate that the return of the reuse of glass bottles is less harmful to the environment than the use of polyethylene terephthalate (PET) plastic [96]. However, we do not have enough time here to argue for or against PET compared to glass. The advantages or disadvantages of the return of reuse of glass are complex. The production of total carbon energy equivalent for both PET and glass and the respective Life Cycle Analysis, the maximization of the volume occupied and weight in transportation; the possibility for introducing contamination hazards etc., might not provide a cut clear result. Therefore, reusing glass bottles in the beverage sector might not replace plastic too soon. However, it is undoubtful that water as a renewable resource has still been captured, cleaned, and enter the production cycle again in both cases. Nonetheless, plastic chemical compounds found in PET bottles would have a minimum of 450 years of environmental impact on the planet [96].

Water cooling in a drinks factory is by far the number one practice, and it is responsible for about $59.5 \%$ of the total water consumption [105]. In a study by Alkaya and Demirer [3], the reduction of cooling water use was implemented in a fruit concentrate and fruit juice company. Closed-circuit cooling system product lines replaced the once-through cooling. At that same time, they recommended reusing cooling water blow-down from the fruit washing process. Such a method has been successfully replicated in other manufacturing sectors and soft drink/beverage manufacturers. In that case, this could be a solution for excessive cooling water consumption in many parts of the world where similar processes are employed.

Rachwał et al. [88] studied the utilization of brewery wastes in the food industry by-products, such as brewer's spent grain, hot trub. Spent grains contain $80 \%$ of water, and they are responsible for $85 \%$ of the total brewer's waste. Consequently, studying water-recovery in spent grain using new technologies could result in substantial water savings [57]. Other measures could be put in place to minimize water consumption during bottle rinsing and, during beer manufacturing, to optimize the reuse of hot water from wort cooling, recover heat from wort boiling, and reuse bottle pasteurizing overflow water [114].

Clean in Place (CIP) is a closed pipe cleaning technique widely used in the beverage, dairy, pharmaceutical, and cosmetic industries to meet high hygiene and food safety standards. Besides, it saves time by avoiding the need to disassemble equipment, hence a much shorter need to have the production come to a halt. Typically, the process is divided into pre-washing, cleaning with detergents or chemical agents, rinsing, and disinfection $[14,69]$. Couto Pereira and Hansen [28], studying CIP process in one beverages' manufacturer, showed that the improvements enabled by the CIP process could reduce both the initial and final rinse time, as well as recover the water from the final rinse.

\section{Dairy}

Milk processing also requires large amounts of water regarding washing, rinsing, cleaning-in-place steps, pasteurizing, UHT processes, chilling, cooling, steam production etc. Membrane Bioreactor (MBR) methods which range from microfiltration (MF) to reverse osmosis (RO), are among the most promising techniques due to them being considered "clean technologies [91]. Studies demonstrate good results with the use of these methods in dairy products around the world $[42,115]$, as well as demonstrated that MBR was convenient through microfiltration, ultrafiltration (UF), nanofiltration (NF), reverse osmosis (RO) or two-stage operations such as NF + NF or RO + RO [115].

Riera et al. [91] studied the potential characterization and water reuse of nanofiltration of UHT flash cooler condensates from a dairy factory and proposed a nanofiltration plant to treat $20 \mathrm{~m}^{3} / \mathrm{h}$ of condensates with $87.5 \%$ water recovery. The economic estimation of costs $\left(€ 0.777 / \mathrm{m}^{3}\right)$ and savings $\left(€ 2.807 / \mathrm{m}^{3}\right)$ allowed the return on the investment $(\mathrm{ROI})$ in 1.29 years. In a study by Meneses and Flores [78], the potential for reuse of cheese whey as water in CIP process operations using combined ultrafiltration and reverse osmosis system was analyzed. The feasibility study took different perspectives, including technological efficiency, safety, and financial needs. A water recovery of $47.03 \%$ was obtained using UF/ 
RO filtration, whereas recovery of $85.65 \%$ was possible when the spray-drying step as part of the integrated system was included. The UF/RO filtration system is efficient enough as the quality of the water recovered is similar to drinking water [78]. In India, an improvement of CIP in the dairy industry was also developed applying mathematical modelings such as the General Algebraic Modeling System (GAMS/software), as well as the treatment of residual water using a reverse osmosis membrane, reducing $33 \%$ water consumption and $85 \%$ wastewater generation [22].

Valta et al. [114] proposed that to minimize water use in dairy processing and the water pollution load, filtering and milk clarification could use the Just-In-Time (JIT) approach when filling up the tanks, which can reduce the need for cleaning the centrifugal separators.

\section{Cattle, pig, sheep, and goat}

The pre-slaughter of farm animals involves a set of management practices to reduce microbial contamination and loss of product quality. Before leaving the farms and being loaded onto trucks to be transported to the abattoir, the animals enter a fasting period to empty the gastrointestinal content. During evisceration, an emptier gastrointestinal tract reduces the risk of rupture of the viscera and facilitates cleaning the intestines and stomachs. Consequently, the total water need is reduced [65]. The fasting period must be at least eight hours before slaughter, not exceeding $24 \mathrm{~h}$ for bovines, sheep, goats, and $18 \mathrm{~h}$ for pigs and horses. Yet, during fasting, the animals should be kept hydrated all the time [20]. After arriving at the slaughterhouse, the animals are unloaded into arrival pens, and the fasting continues. Still, water should be available to allow the animals to de-stress after the journey. As for pigs, automatic dispensing of water drinking troughs is preferable to reduce waste and avoid the accumulation of dirt. Water is a good regulator for maintaining the animal's body temperature and hydro electrolytic maintenance.

Furthermore, when held in reception pens, the cattle should also be protected from direct sun and have adequate ventilation. In tropical countries, environment conditions should be improved such as the presence of fans that circulate the air around the animals is deemed essential. In addition, in warmer and drier regions, water sprinklers can also reduce the temperature of the environment and maintain the relative humidity of the air suitable for animals in reception pens. Yet, such a practice could be replaced by air-conditioning systems.

Water is generally used to clean the livestock transport trucks and the reception pens, which need to be cleaned frequently. However, dry cleaning methods can also be employed before using water. For example, larger solids can be removed with brooms, squeegees, or shovels, reducing consumption by $20-30 \%$ of water at this stage of the process alone. A final rinse can be then carried out during which cleaning staff aims to hit the floor and surfaces at an angle of up to $60^{\circ}$ in order to improve cleaning efficiency [106]. Moreover, regularly monitoring spray nozzles and pressure reducers, and shut-off valves to reduce water consumption. Therefore, the reception pens should be designed with water-saving in mind by constructing, layout, materials, and type of flooring to facilitate dry removal as possible [106].

In a conventional slaughter system, the bleeding of cattle and pigs should be quick, and it should not last more than 7 minutes. Being the blood a compound with high biochemical oxygen demand, as long the bleeding time, higher will be the amount of blood collected, that will not go to the affluent, reducing the treatment demand and environmental pollution [120]. As for an alternative during bleeding, a two-way blood drainage system could be considered. This consists of two drainage outlets, one connected to the blood barrel and another to a septic tank. This would allow one outlet to be opened while the other is closed, particularly at the end of the slaughter when all the blood had been swept into the collection drum; all the wastewater would then be directed to the septic tank. Therefore, a more efficient separation of the blood and wastewater would also enable blood as a by-product to be processed [65].

Particularly in the slaughter of pigs, the scalding stage by immersion involves using the constant flow of heated water where the refilling/filling of the tank must be controlled by a valve or other device to avoid waste by overflow. The tank should have a slight slope in the bottom favoring drainage to facilitate the removal of solid residues from the tank when cleaning using less water $[36,37,84]$. Immersion scalding is currently the most used method in slaughterhouses. Still, there are already other techniques that achieve the same objective that use less water, such as scalding using hot water spray, steam, or condensation, where the use of water is more efficient and controlled [106, 120].

In the viscera's cleaning stage, water is used to wash off the entrails. Therefore, the fewer feces there are, the easier this cleaning will be, and it is recommended to stop feeding the animal a few hours before the farm animals are shipped to the slaughterhouse. Still, at this stage, the idea is to do a dry cleaning of the frames before washing with water, thus reducing their consumption $[65,97,120]$. 
The presence of automation and the use of robotics in slaughterhouses is increasing. Yet, the equipment requires constant cleaning to keep hygiene standards high. For example, automatic eviscerators require a continuous flow of water during the entire process. And, when the production process has to be interrupted, then the water flow should stop to avoid wasting of running water. This would be possible by installing a water waste control system as proposed by Pacheco and Yamanaka [84].

During slaughter, solid materials are produces at several stages. For this, an efficient collection of these by-products that would be thrown away could be used to manufacture flour for animal feed instead of throwing them down the drain. Drains equipped with screens and siphons can retain this material to be directed to the grease company, preventing it from going along with the rest of the effluent [106].

Furthermore, a simple and ancient method of using water is to collect rainwater, which can be stored in cisterns and, after being treated using flocculation and chlorine, rainwater could later be used for cleaning reception pens or in other places where drinking water is not required [10]. Rainwater harvesting has seen a resurgence as an alternative to better manage water resources. The collection and use of rainwater can be valuable to washing livestock transport trucks, reception, and waiting pens [10]. This practice can be used in any kind of industry. The capture of rainwater could also be essential to avoid rainwater from entering the animals' slurry collecting system. In countries where the Environmental Agency imposes strict slurry control measures, managing slurry contention tanks is constantly worrying farm managers. Often, rainwater enters the slurry collection system, leading to excess liquid in the slurry pools. Using data from the Meteorological Office (MetOffice) in the United Kingdom, a rapid appraisal was carried out by one of the authors of this chapter in a mixed farm (sheep, cattle, dairy, and pig) in the West Midlands. The total potential of rainwater that precipitated over most of the farm buildings, if collected, would be the equivalent to the annual abstraction of water from one borehole also in that same farm. The figure indicated that about $22,152 \mathrm{~m}^{3}$ of rainwater could be potentially collected from the farm buildings, which could then be used during activities that, for example, would not require potable quality water, such as washing the floors. The rainwater capture would also avoid rainwater runoff to "contaminate" the slurry, which is currently the case. This would also provide some relief, particularly during the winter months, of excess liquid slurry being stored until the weather gets warmer to start to be spread in the pastures.

\section{Poultry}

As for poultry slaughter, good practice recommends that water and food fasting should start six hours before the slaughter of the birds but not exceeding 12 hours [20]. At arrival, poultry should remain in climate-controlled waiting rooms to reach the point of thermal comfort. This would depend on the weather and the climatic conditions for specific countries. However, poultry should be protected from wind, rain, direct sunlight, and adequate ventilation and humidity [12]. Suppose the dimensions and density of the cages are calculated to allow good circulation of air to the birds and the construction of the reception area, which should provide a suitable shaded microclimate. In that case, water use by sprinklers could be reduced in hot weather situations.

Before slaughtering poultry, a change in the stunning method could represent significant savings in water consumption. Electronarcosis stunning by immersion in water requires a tank with water changing in every shift. In addition, the level of water has to be kept high to allow for the poultry's head, while hanging upside down by their feet can touch the water, which is charged with an electric current. Yet, gas stunning, a practice used in many countries, such as England and Netherland [12], or dry electronarcosis used in pigs are techniques that have considerably reduced water use.

According to Amorim et al. [5], the scalding and plucking stages in the slaughter of birds represent half of the total water consumption used during the entire process. To reduce this waste of water, during scalding, the size of the tank can be reduced while respecting the time-temperature binomial, or else change the conventional process of immersion in hot water to scalding by spraying hot water and steam.

Another critical aspect in poultry processing is pre-cooling, a stage after slaughter during which the carcass temperature must be brought down to $7^{\circ} \mathrm{C}$ to create a hurdle for bacterial proliferation. The carcass temperature must get cooled as fast as possible but respecting the binomial time vs. temperature for it not being too quick, which would impact the quality of the meat or too slow, creating an opportunity for bacterial contamination. Therefore, cooling can be done in different ways. At pre-cooling, carcasses can be immersed in cold water. When this practice is used, a reduction in water renewal flow in cooling tanks is recommended. However, the present-day best alternative approach to saving water in pre-cooling is to replace water immersion for air refrigeration. In the air-cooling system, poultry goes through a tunnel 
with air cooling with or without a water spray [11]. The advantage is that water used during scalding and pre-cooling can be reused in most poultry processing plants to drain, such as flushing offal and feathers [113].

Other simplified procedures in the slaughterhouse catering for all animal species could further reduce water consumption. For example, it is well known that the installation of taps with automatic and timed closing for hand washing and showers is a proven method that reduced water wasting [59]. Other methods that also save water are mechanical cleaning of the solids (dry cleaning) before water washing takes place. When the bulk of the dirt is removed, then the use of water is shorter and more efficient. The same can be said when washing floors. The use of pressurized nozzles also reduces the overall water flow and aids in the dislodging some dirt attached to surfaces. When effluent cleaner water can be used in areas where drinking water standard is not needed there are clear gains in water savings, energy and water treatment such as in pre-washing of residues such as grease for the production of tallow and flour for animal food feed $[5,33]$. Water reuse and effluent reduction techniques, already discussed previously, can be adapted to the slaughtered poultry from other species and other food industries. Cold production is also required to maintain rooms, such as the deboning room, at a constant $10^{\circ} \mathrm{C}$ using air-conditioning. In air-conditioned cutting rooms and chilled chambers correspond to large areas in a processing plant. Consequently, for cold generation, water-cooled ammonia refrigeration systems are commonly used [11].

\section{Fish}

According to Gabardo and Santos [45], fish must fast $24-48 \mathrm{~h}$ before slaughter, and as good practice, the intestines should be empty at the time of slaughter. As previously mentioned, for slaughtering other species, it is possible to significantly reduce the amount of water by changing the layout and some handling techniques, such as high-pressure hoses and flow controllers, automatic activation of the taps well as possible monitoring leaks. Water consumption in a tilapia processor establishment has almost halved [6].

In fish processing, the stages of stunning with ice (thermo-narcosis), bleeding, washing, desquamation, cut off the head, it is also possible to save water by substituting the continuous flow of water for that of a batch system, i.e., using immersion of the fish in ice water. Another stunning method used in fish is electronarcosis. In the work of Lines and Kestin [70], several slaughter methods for trout were compared: stunning by $\mathrm{CO}_{2}$, bleeding from the gills, thermal shock, and electrical stunning. They concluded that single-phase electrical stunning for $60 \mathrm{~s}$ and $1000 \mathrm{~Hz}$ electrical current, despite causing bleeding in the animal, causes minor damage to the housing.

The use of pressure nozzles in the processing and cleaning of fish allows water savings that, together with reducing the number and size of spray nozzles, can save up to $75 \%$ of the volume of water. Regarding the filleting process, when unnecessary nozzles are removed, there is a $60-75 \%$ reduction in water consumption at this stage $[6,113]$. In addition, during the thawing of fish, Valta et al. [113] recommended using immersion in a water container where water was mixed with bubbling air while the water recirculation level was kept constant. That allowed for better control of the temperature and a reduced need for water renewal.

\section{Water recycling and reusing in the food industry}

The practice of partial or total water recycling and reusing can be applied to any food production process. However, there are countless contaminants carried by water, such as bacteria, viruses, parasites, natural toxins, chemicals, pesticides, and heavy metals, making it necessary to carry out microbiological and physical-chemical analysis before its use. Drinking water must not contain pathogenic microorganisms that indicate fecal contamination as expressed by the coliform count. Through the microbiological analysis of water, the presence of non-pathogenic and pathogenic microorganisms can be identified, the latter being the most important concerning public health and food poisoning that can even lead to death. As for physical analyzes of water a range of tests can be used to measure changes in water quality. Firstly, since water should be colorless, any changes on color in water indicates turbidity or how murky that water can be. Turbidity can be an indication of organic matter suspended in water, therforefore the presence of microorgnisms such as bacteria and phytoplankton. Beyond water being colorless, it should also have no smell and no taste. However, the presence of chemical compunds residues such as calcium indicating hardness, ammonia, ammoniacal nitrogen, nitrates, nitrites, aluminum, iron, and heavy metal can be good indicators of contamination that could be detrimental to health [59]. So, periodic analyzes of these components must be carried out. In relation 
to water chlorination, analyzes must be carried out several times throughout the day by the inspection service and by the company's quality control Environmental Protection Agency (EPA) Surface Water Treatment Rule requires a minimum disinfectant residual of $0.2 \mathrm{mg} / \mathrm{L}$ for water entering the distribution system and that a detectable level be maintained throughout the distribution system [109]. The World Health Organization (WHO) has suggested that, for areas with little risk of cholera or related outbreaks, a free chlorine residual range of $0.2-0.5 \mathrm{mg} / \mathrm{L}$ be maintained at all points in the supply [119].

Thus, to meet these parameters in reuse water, we need to treat it. As stated earlier, MBR is a modern and promising technology for the treatment of effluents before the reuse of water within the food industry itself [24], having several benefits in relation to conventional systems, combining a biological process with membrane separation [61, 108].

Going further, synthesizing nanomaterials is possible by incorporating new membranes with specific properties in MBR systems for wastewater treatment. The use of nanotechnology, a science of the next generation, in MBR, improves the performance and efficiency of the process, with minor encrustation and greater efficiency in removing pollutants, promoting greater sustainability in the use of water and generation of environmental pollutants [85, 87]. Ferraciolli et al. [41] evaluated the extent of the potential of effluent reuse in fish processing. They found out that low organic load effluent resulting from evisceration and washing equipment could be reused after treatment, particularly after removing the solids.

The reuse of water can be direct or indirect. The indirect use occurs when water is discharged into the environment and eventually captured and used again in its diluted form. After being treated, immediate use occurs when the effluents are sent directly from their discharge point to holding tanks or pools, thus not being discharged into the environment [67]. Current environmental legislation in many countries provides that any effluents should be treated and recycled within a system. In the case of solids resulting from slurry production, they should be separated before the liquid phase could be either spread on fields or treated and re-introduced to the environment.

Currently, there are several techniques available to treat effluents in industrial plants. Typically physical-chemical effluent treatments can be found in urban water effluent water pants consisting of floation, decanting and chlorinating. In some systems, biological treatment of efluents which use specific bacteria aids in the breaking down of organic matte. These ca be aerobic, as mentioned before or anaerobic. In anaerobic treatment, without the presence of oxygen, typically used as a pre-treatment of water, anaerobic digesters breakdown organic matter and, as a by product, both $\mathrm{CO}_{2}$ and methane gas are produced. In recent years, artificiaaly built wetlands have been intrduced as an alternative to water treatment allowing for the natural breaking down of organic matter promoted by natural biological process. Electrochemical water treatment methods are rare but effective in treating industrial effluents. Particularly, the electric current coagulates all chemical compounds, including ions, diluted in the acqueous medium. Membrane bioreactors tend to be used in sludge treatment in urban water works. Yet, the type of treatment will depend on the scale, the purpose and the investment needed as sine if the aforementioned methods can be costly [1, 34, 99].

Biological processes are generally based on decanting and natural degradation of the organic matter in the effluent. For this purpose, the microorganisms of the effluent itself are used, which, with the introduction of air, end up carrying out the water treatment task. Yet, the effluent also requires to be disinfected. This can be done using physical-chemical processes, such as chlorine or UV, among others [67]. The specific type of effluent treatment would depend on the initial water quality and the purpose of its secondary use $[64,67]$.

Depending on the level of treatment conferred to reused water, it can be also used for the purpose of, for example, fire protection reserve; aquatic decorative systems, such as fountains and fountains, water mirrors; flushing public toilets; ground dust control; garden irrigation; cooling towers; boilers; civil construction and soil compaction; washing floors, vehicles, industrial warehouses, and some mechanical parts and equipment; use in industrial processes and aquifer recharge [100]. Reused water can also be used for irrigation in agriculture cultures, such as lettuce [95] and microalgae cultivation [71]. Some studies suggest this previous treatment of wastewater by wetlands construction [75, 79].

For example, Brazilian law allows the reuse of water only for non-potable purposes. In contrast, in other countries, reuse water can also be used for drinking purposes, of course, after treatment. Direct drinking reuse for public supply is already established in several American states, South Africa, Australia, Belgium, Namibia, and Singapore, without any associated public health problems [56]. The World Health Organization follows HACCP guidelines for water reuse risk-management [118]. The "guidelines for the safe use of wastewater, excreta, and greywater" apply to wastewater in agriculture, aquaculture, sewage, and treatment in industrial plants. This is true to the USA [110], Australia [52, 102], and the European Union [4, 17]. Furthermore, the Codex Alimentarius establishes the reuse of treated effluents from food manufacturing must consider the likely potential control of pathogenic microorganisms $[26,68]$. The UNEP [106] 
recommends the reuse of wastewater from cooling systems and vacuum pumps for the purpose of washing livestock in reception pens.

Depending at what stage the water reused would be needed, it might not be necessary to reach drinkable status. Therefore, it is possible to pre-treat the water through coagulation, flocculation, sedimentation, filtration, and chlorination. It is important to note that in food industries, the procedure in use that allows for that return of water to the natural watercourse with COD should be lower than at the point collected and must also comply with the environment [82].

Other water treatment methods have been studied. Barrera et al. [15] looked at vacuum-ultraviolet and ultraviolet-C processes in the reduction and degradation of total organic carbon and bacteria in secondary effluent of slaughterhouse wastewater. Biodigesters have been effective in breaking down effluents and blood to generate energy [66, 117]. Energy can be fed to the national grid or used during processing such as lighting and the heating-cooling systems $[32,50,55$, $72,73,116]$.

Another possibility recently studied to treat wastewater from food industries is enzymes [9]. Some studies have considered the use of enzymes such as Laccases which catalyze the oxidation of phenolic compounds $[13,77]$ and effluent detoxification $[8,90]$.

Another way to reuse water is through treatment using MBRs systems, as already described earlier in this chapter, as a sound system used in different food industries. In establishments that dispose of effluents with high biochemical oxygen demand, this type of treatment can be very advantageous, offering an opportunity for food companies to achieve almost zero disposal of their waste $[47,101]$.

With the advancement of new technologies and Industry 4.0, industries should have environmental awareness and implement environmentally friendly and sustainable systems. However, simple and less expensive methods can also be adapted.

\section{Industry 4.0}

In recent years, an increasing number of research outputs have been coming to light, particularly how companies can adapt to the changing market environment to new production methods and processes regarding sustainability. Implementing innovative solutions in conjunction with artificial intelligence and augmented reality $[19,86]$ has been deemed of extreme importance in the development of new scientific research applications. It is expected that the introduction of information technology (IT) in the food sector would enable advanced solutions to the food industry.

Industry 4.0, also called the Fourth Industrial Revolution, is a new concept that mobilizes companies worldwide to use cutting-edge technology, creating an intelligent production system, to enable the creation of "intelligent factories" based on high-quality systems. Technology [18]. It could be compared to the industrialization in the manufacture of food during the last century, which allowed the production of food to increase 100 times. Regarding beverages, also in the previous century, the jump in production was from 100 bottles per hour, intensively dependent on human labor, to 10,000 units per hour with the aid of machines. Industry 4.0 would then be expected to bring further gains in production, hence becoming a milestone of the same magnitude in world production of food and beverage [7].

Industry 4.0 emphasizes information and communication technologies as one of the four main technological areas: information and communication technology, technologies to ensure vital resources (food, water, and energy needs), new technologies, manufacturing, and automation. The definition of Industry 4.0 consists of nine pillars, according to Vaidya et al. [112].

\subsection{Big data e data analytics}

Intelligent systems that can collect, organize and analyze a vast amount of data from different sources to improve and automate industrial processes and are responsible for identifying process failures, improving product quality in real-time, and efficiency in the use of all productive resources. 


\subsection{Autonomous robots}

In the fourth revolution, robots are much more than simple machines that follow schedules, and now they can work intelligently, interacting with other machines without human supervision and autonomously, reducing labor costs. Work and increases production, making industries more competitive.

\subsection{Cloud computing}

Fast and interconnected systems, with access to the database and support from any location, with the full integration of industrial plants.

\subsection{Internet of things (IoT) in industry}

All technologies connected by sensors and connected to the internet. Everything that happens in an industrial plant is registered on the internet. Sensors are responsible for generating and analyzing data (data analytics), expanding the ability to make decisions in real-time, and allowing access and control throughout the production process.

\subsection{Simulation}

The entire creation chain can be simulated virtually in industry 4.0. The virtual environment can involve products, materials, machines, processes, and people, allowing methods and products to be tested, reducing failure costs and design time.

\subsection{Systems integration}

IT systems interconnected within companies, with universal data-integration networks (ERP, MES, SAP) that vertically and horizontally integrate the entire production chain to facilitate data analysis and decision making.

\subsection{Cybersecurity}

Cybersecurity, cybersecurity or cybersecurity, is essential in industry 4.0 and a consequence of the other pillars. With highly connected and integrated management to the internet, protecting data and systems is fundamental and can be pretty challenging.

\subsection{D printing}

Additive manufacturing allows production using 3D printers. For the production of physical prototypes and customized parts, or for the rapid manufacture of complex factors, which in the traditional process model involves high costs of customization, manufacture, and transportation.

\subsection{Augmented reality}

It is the visual overlap of real and virtual objects that can facilitate the operation of machines and maintenance services, allowing an increase in productivity and cost reduction in manufacturing processes, in addition to saving resources.

Thus, with the implementation of these new technologies, the situation in the entire food industry will change dynamically. It is already improving and will further enhance many areas in the food chain in the next few years. According to Borowski [18], the implementation of Industry 4.0 will allow companies to implement new products and production methods, obtain better results and competitiveness, reduce production costs, and save water and 
energy, both so important in the current world of $\mathrm{CO}_{2}$ emissions. Thus, in addition to reducing costs, this type of intelligent industry meets the environmental requirements necessary for preserving the planet's natural resources.

We can cite examples of these pillars about the sustainable use of water, such as augmented reality. For example, Equipment operators could use 3-D Glasses or special tablets to certify cleaning routine and cleaning checklist in food factories. Therefore, the control would be much more efficient and safer, as information would be displayed on what needs special attention and where the critical control points are throughout the process. They could provide visual guidance on where water costs are highest and correct them when necessary, redundant downtime, and, consequently, increasing the effectiveness of the process in general [19]. Also integral to HACCP, verification and documentation could be stored online and be fed to blockchain systems. Consequently, within Industry 4.0, "Water 4.0 " is a concept that has recently been touted as the "future" of the water industry.

Artificial intelligence (Al) systems can do risk detection better than humans in real-time, ensuring safer, more accurate, faster, and more consistent results during production. Al is of great importance in optimizing water resources, with better control of cleaning and hygiene processes in the food industry, reducing the final cost of production. These controls, being robotic and automated, can constantly operate $24 \mathrm{~h}$ a day $[44,46,49,54,98]$.

According to Arora and Sharma [8], a way to reduce water consumption in the food industry would be to implement efficient pumping using variable speed pump (VSD) controls that offer various functions via software, such as regulating pressure and flow parameters. Water for cleaning tubes in CIP equipment, reducing cleaning time and reducing the amount of water consumed during the process. There is also anti-cavitation software, which detects and prevents cavitation, ensuring the optimal flow of water throughout the plant, in addition to increasing the pump's life. The choice of machinery also reflects water use; it is important to choose equipment that is easy to clean, taking less time, and requiring less water, i.e., stainless-steel washdown motors, gearboxes, and mounted bearings with smooth, crevice-free surfaces.

The food and beverage industry can also benefit from intelligent sensors to detect and calculate the actual water needed for each process. Running a more sustainable, energy-efficient food and beverage manufacturing plant is possible by using technology to minimize carbon and water footprint. Following the global trend, companies must be environmentally conscious, focusing on energy efficiency and sustainable use of water, knowing that the money invested in the implementation of new facilities and equipment will return in the form of cost reduction and added value to the product.

There are already digital industrial plants, fully integrated, with minimal losses and little human interference in most processes. Specifically in the food industry, we already have highly mechanized and automated plants, such as cheese production plants. Operators control parameters from a control room via computers, and the process takes place without any human interference, except during preventive or corrective maintenance. Even for repairs, there are already autonomous systems that only activate a human being as a last resort after all the solutions programmed in the system have been exhausted [81]. However, these intelligent systems depend on a cutting-edge internet. Highly robotic slaughterhouses it $1 \mathrm{~s}$ also a reality. The entire flowchart is automated, from the reception of the animals to the complete deboning and packaging with minimum losses during the process, optimizing water energy use, reducing costs production, and adding value to the final product.

In this way, many losses will be minimized through exact calculations generated by Al, being possible, for example, to calculate the precise amount of renewal water necessary for the pre-cooling of birds carcasses, or for the scalding process of birds and pigs., or to make a rational use of or replace the spray bath prior to the stunning of bovines, as well as in the washing of bovine carcasses before entering the cold chambers, or losses of meat that are adhered to the bones after a bad deboning, or else detect any type of leak that may be happening in the company in real-time, draw better logistical plans reducing unnecessary losses, among many other points, being practically everything better reused with the minimum of human intervention, where the decisions of when to call, shut down or when to accelerate or reduce production, in the manufacturing environment, become automated and carried out by machines, being capable of detecting any type of irregularity in advance, with maximum control and in real-time.

Food companies increased investment in automation and the robotization of dynamic progress, observing as a result, an improvement of the product as well as reduction of production costs [43], which is associated with setting the limits of process efficiency [31]. Food processing with minimal expenditure on natural resources, including water, will certainly reduce the impact of the ecological footprint caused by this sector [63]. Clean production methods, together with advances in robotics and artificial intelligence, within Industry 4.0, should lead to a new phase of water use in the coming years within the food industry. 


\section{Conclusions}

Despite all the current and predicted changes, water will remain a natural asset of great value to humanity. Consequently, its use should still deserve the utmost care to enable future populations to access good quality clean water.

Water is an essential and invaluable resource for the food industry. Many aspects regarding the more efficient use of water were addressed, however, these have not been exhausted here. In the light of increasing water scarcity due to environmental degradation, pollution, and climate change, managers in the food industry should be more alert to cleaner production methods. During the production and processing of food, cleaner production methods can mitigate water scarcity. It is already a reality in many industries, but more still could be done regarding implementation and research, and technology adoption grant investments. Proposals and suggestions for techniques presented in this chapter allow the food and beverage industry to minimize the waste of this natural resource while also mitigating the production of effluents and consequently their pollution. Thus, companies will reduce impacts on the environment and reduce costs and add value to the final product.

Authors' contributions All authors participated and contributed to this manuscript publication by reviewing the literature, structuring the article and translating it into English. All authors read and approved the final manuscript.

\section{Declarations}

Competing interests The authors declare no competing interests.

Open Access This article is licensed under a Creative Commons Attribution 4.0 International License, which permits use, sharing, adaptation, distribution and reproduction in any medium or format, as long as you give appropriate credit to the original author(s) and the source, provide a link to the Creative Commons licence, and indicate if changes were made. The images or other third party material in this article are included in the article's Creative Commons licence, unless indicated otherwise in a credit line to the material. If material is not included in the article's Creative Commons licence and your intended use is not permitted by statutory regulation or exceeds the permitted use, you will need to obtain permission directly from the copyright holder. To view a copy of this licence, visit http://creativecommons.org/licenses/by/4.0/.

\section{References}

1. Abdallh MN, Abdelhalim WS, Abdelhalim HS. Industrial wastewater treatment of food industry using best techniques. Int J Eng Sci Invent. 2016;5(8):15-28.

2. Aguiar LK, Caleman SMQ, Agrodefesa (Agência Goiânia de Defesa Agropecuária). Gerência de inspeção produtos de origem animal: normas de construção abatedouro de aves. Sustainability: who is driving it?, vol. 1. 1st ed. Campo Grande: Revista Desafio Online; 2013.

3. Alkaya E, Demirer GN. Water recycling and reuse in soft drink/beverage industry: a case study for sustainable industrial water management in Turkey. Resour Conserv Recycl. 2015;104:172-80.

4. Alcalde-Sanz L, Gawlik BM. Water reuse in Europe: relevant guidelines, needs for and barriers to innovation. JR Sci Policy Rep. 2014. https://doi.org/10.2788/29234.

5. Amorim AKB, De Nardi IR, Del Nery V. Water conservation and effluent minimization: case study of a poultry slaughterhouse. Resour Conserv Recycl. 2007;51(1):93-100. https://doi.org/10.1016/j.resconrec.2006.08.005.

6. Araújo C. Consumo de água em frigoríficos de pescado pode cair até quase $50 \%$. Empresa Brasileira de Pesquisa Agropecuária (EMBRAPA). 2017. https://www.embrapa.br/busca-de-noticias/-/noticia/25135189/consumo-de-agua-em-frigorificos-de-pesca do-pode-cair-ate-quase-50.

7. Arbegaus AA. Indústria 4.0 e o setor de alimentos e bebidas. Tecnológica. 2018. https://blog.teclogica.com.br/industria-4-0-e-o-setorde-alimentos-e-bebida/. Accessed 06 May 2021.

8. Arora DS, Sharma RK. Ligninolytic fungal laccases and their biotechnological applications. Appl Biochem Biotechnol. 2010;160(6):1760-88. https://doi.org/10.1007/s12010-009-8676-y.

9. Bail J. Lacase e suas aplicações biotecnológicas: uma revisão. Rev Cient Multidiscip Núcl Conhecimento. 2020;14(10):21-30.

10. Bailone R, Roça R, Fukushima H, De Aguiar LK. Sustainable water management in slaughterhouses by cleaner production methods-a review. Renew Agric Food Syst. 2020. https://doi.org/10.1017/S1742170520000083.

11. Bailone RL, Roça RO. Trends in processing broiler: rational use of water. Eng Sanit Ambient. 2017;22(1):65-72. https://doi.org/10.1590/ s1413-41522016154650.

12. Bailone RL, Roça RO, de Aguiar L, Harris MJ. Main technical differences in the processing of broilers: a comparison between slaughterhouses in Brazil and UK. J Agric Sci Technol A. 2016. https://doi.org/10.17265/2161-6256/2016.02.007.

13. Baldrian P. Fungal laccases-occurrence and properties. FEMS Microbiol Rev. 2006;30(2):215-42. https://doi.org/10.1111/j.1574-4976. 2005.00010.x. 
14. Bansal B, Chen XD. A critical review of milk fouling in heat exchangers. Comp Rev Food Sci Food Safety. 2006;5(2):27-33. https://doi.org/ 10.1111/j.1541-4337.2006.tb00080.x.

15. Barrera M, Gilbride KA, Mccarthy LH, Laursen AE, Bostan V, Pushchak R. Photolytic treatment of organic constituents and bacterial pathogens in secondary effluent of synthetic slaughterhouse wastewater. Chem Eng Res Des. 2012;90(9):1335-50. https://doi.org/10. 1016/j.cherd.2011.11.018.

16. Bastos MDSR. Frutas minimamente processadas: aspectos de qualidade e segurança. Fortaleza: Embrapa agroindústria tropical. 2006. http://www.agencia.cnptia.embrapa.br/Repositorio/frutasminimamenteprocessadas_000fdejd97n02wx5eo0a2ndxyb8wg7w1.pdf. Accessed 25 May 2021.

17. Bixio D, Wintgens T. Water reuse system management manual-AQUAREC. Luxembourg: EC; 2006.

18. Borowski PF. Innovative processes in managing an enterprise from the energy and food sector in the era of industry 4.0. Processes. 2021;9(2):381. https://doi.org/10.3390/pr9020381.

19. Borowski PF. New technologies and innovative solutions in the development strategies of energy enterprises. HighTech Innov J. 2020;1:39-58. https://doi.org/10.28991/HIJ-2020-01-02-01.

20. Brasil. Regulamento técnico de manejo pré-abate e abate humanitário. Berlin: Diário Oficial da União do Brasil; 2018.

21. The Brewers of Europe. The environmental performance of the European brewing sector (full report). 2012. http://www.brewersofe urope.org/docs/publications/2012/envi_report_2012_web.pdf.

22. Buabeng-Baidoo E, Mafukidze N, Pal J, Tiwari S, Srinivasan B, Majozi T, Srinivasan R. Study of water reuse opportunities in a large-scale milk processing plant through process integration. Chem Eng Res Des. 2017;121:81-91. https://doi.org/10.1016/j.cherd.2017.02.031.

23. Casani S, Rouhany M, Knøchel S. A discussion paper on challenges and limitations to water reuse and hygiene in the food industry. Water Res. 2005;39(6):34-1146. https://doi.org/10.1016/j.watres.2004.12.015.

24. Cassano A, Rastogi NK, Basile A. Membrane technologies for water treatment and reuse in the food and beverage industries. In: Advances in membrane technologies for water treatment. Sawston: Woodhead Publishing; 2015. p. 551-80. https://doi.org/10.1016/B978-1-78242121-4.00018-6.

25. Cetesb (Companhia Ambiental do Estado De São Paulo). Guia técnico ambiental de abates (bovino e suíno). São Paulo: Cetesb; 2006. p. 98. https://cetesb.sp.gov.br/consumosustentavel/wp-content/uploads/sites/20/2013/11/frigorifico.pdf.

26. CODEX. Codex Alimentarius Commission: Codex Committee on Food Hygiene. Thirty-fourth session: proposed draft guidelines for the hygienic reuse of processing water in food plants. Bangkok: Codex Alimentarius Commission; 2001. p. 8-13.

27. Compton M, Willis S, Rezaie B, Humes K. Food processing industry energy and water consumption in the Pacific northwest. Innov Food Sci Emerg Technol. 2018;47:371-83. https://doi.org/10.1016/j.ifset.2018.04.001.

28. Couto Pereira L, Hansen É. Wastewater reuse in the clean in place process of a beverage industry. ITEGAM JETIA. 2020;6(21):47-54. https:// doi.org/10.5935/2447-0228.20200006.

29. CPTS: Centro de Promocíon de Tecnologías Sostenibles (Bolívia). Guía técnica de producción más limpia para mataderos de Bovinos. La Paz: CPTS; 2009. p. 208.

30. CPTS: Centro de Promocíon de Tecnologías Sostenibles (Bolívia). Guía técnica de producción más limpia para mataderos de Porcinos. La Paz: CPTS; 2009. p. 177.

31. Cyfert S. System granic architektury procesów organizacji-determinanty kształtowania i dysfunkcji w definiowaniu (the system of organizational process architecture boundaries-determinants of shaping and dysfunction in defining), vol. 340. Wroclaw: Research Papers of the Wroclaw University of Economics/Prace Naukowe Uniwersytetu Ekonomicznego we Wroclawiu; 2014. p. 243-50.

32. Dababat SS, Shaheen HQ. Biogas production using slaughterhouse wastewater co-digested with domestic sludge. J Civ Eng Constr. 2019;8(1):34-40. https://doi.org/10.32732/jcec.2019.8.1.34.

33. De Aguiar Camargo J, Henkes JA, De Fátima Rossato I. Avaliação do consumo de água em abatedouro de aves visando a redução e ou reutilização de água. Rev Gest Sust Ambient. 2016;5(2):675-93. https://doi.org/10.19177/rgsa.v5e22016675-693.

34. De Gisi S, Notarnicola M. Industrial wastewater treatment. In: Abraham M, editor. Encyclopedia of sustainable technologies, chapter: module in Earth system and environmental sciences. 1st ed. Amsterdam: Elsevier; 2017. p. 23e42. https://doi.org/10.1016/B978-0-12409548-9.10167-8.

35. Eckhard CL. Aplicação do método de Produção Mais Limpa: estudo de caso em uma indústria de candies (Master's thesis). Centro Universitário Univates; 2014. https://www.univates.br/bdu/bitstream/10737/608/1/2014ClaudioLuizEckhard.pdf.

36. Environment Agency. Dairy and milk processing sector (EPR 6.13). 2009a. http://cdn.environment-agency.gov.uk/geho0209bpix-e-e. pdf. Accessed Feb 2014.

37. Environment Agency. The red meat processing (cattle, sheep and pigs) Sector (EPR 6.12). 2009b. http://cdn.environment-agency.gov. uk/geho0209bpja-e-e.pdf.

38. Environment Agency. Treating and processing poultry (EPR 6.11). 2009c. http://cdn.environmentagency.gov.uk/geho0209bpiz-e-e.pdf.

39. European Union. Directive (EU) 2020/2184 of the European Parliament and of the Council on the quality of water intended for human consumptio (recast). 2020. https://www.legislation.gov.uk/eudr/2020/2184.

40. FAO. Food and Agriculture Organization of The United Nations. The future of food and agriculture-trends and challenges. Rome. 2017. http://www.fao.org/3/a-i6583e.pdf. Accessed 06 May 2021.

41. Ferraciolli MRLDV, Luiz DDB, Naval LP. Potential for reuse of effluent from fish-processing industries. Ambiente \& Água - An Int J Appl Sci. 2017. https://doi.org/10.4136/ambi-agua.2045.

42. Fraga FA, Garcia HA, Hooijmans CM, Miguez D, Brdjanovic D. Evaluation of a membrane bioreactor on dairy wastewater treatment and reuse in Uruguay. Int Biodeterior Biodegrad. 2017;119:552-64. https://doi.org/10.1016/j.ibiod.2016.11.025.

43. Frąs J, Czyrka K. Instruments for shaping the quality of production processes in the conditions of coopetition of enterprises. Adv Intell Syst Comput. 2020;1216:235-44. https://doi.org/10.1007/978-3-030-51981-0_30.

44. Funes $E$, Allouche $Y$, Beltrán $G$, Jiménez $A$. A review: artificial neural networks as tool for control food industry process. J Sens Technol. 2015;5:28-43. https://doi.org/10.4236/jst.2015.51004.

45. Gabardo BI, Santos CB. Abate de peixes e seu impacto sobre a qualidade do produto. 1st ed. Curitiba: Universidade Federal do Paraná; 2019. 
46. Garcia-Esteban JA, Curto B, Moreno V, Gonzalez-Martin I, Revilla I, Vivar-Quintana A. A digitalization strategy for quality control in food industry based on Artificial Intelligence techniques. In: Proceedings of the IEEE 16th International Conference on Industrial Informatics, INDIN 2018, Porto, Portugal, 18-20 July 2018. New York: Institute of Electrical and Electronics Engineers Inc.; 2018. p. 221-6.

47. Garg S, Chaudhry S. Treatment of wastewater of food industry by membrane bioreactor. Int Adv Res J Sci Eng Technol. 2017;4:153. https:// doi.org/10.17148/IARJSET.2017.4628.

48. Gil MI, Selma MV, López-Gálvez F, Allende A. Fresh-cut product sanitation and wash water disinfection: problems and solutions. Int J Food Microbiol. 2009;134(1-2):37-45. https://doi.org/10.1016/j.ijfoodmicro.2009.05.021.

49. Goyache F, Bahamonde A, Alonso J, Lopez S, Del Coz JJ, Quevedo JR, Ranilla J, Luaces O, Alvarez I, Royo LJ, et al. The usefulness of artificial intelligence techniques to assess subjective quality of products in the food industry. Trends Food Sci Technol. 2001;12:370-81. https:// doi.org/10.1016/S0924-2244(02)00010-9.

50. Granada CE, Hasan C, Marder M, Konrad O, Vargas LK, Passaglia LM, Sperotto RA. Biogas from slaughterhouse wastewater anaerobic digestion is driven by the archaeal family Methanobacteriaceae and bacterial families Porphyromonadaceae and Tissierellaceae. Renew Energy. 2018;118:840-6. https://doi.org/10.1016/j.renene.2017.11.077.

51. Gumbo B, Mlilo S, Broome J, Lumbroso D. Industrial water demand management and cleaner production potential: a case of three industries in Bulawayo, Zimbabwe. Phys Chem Earth. 2003;28(20-27):797-804. https://doi.org/10.1016/j.pce.2003.08.026.

52. Hamilton AJ, Boland AM, Stevens D, Kelly J, Radcliffe J, Ziehrl A, Paulin B. Position of the Australian horticultural industry with respect to the use of reclaimed water. Agric Water Manag. 2005;71(3):181-209. https://doi.org/10.1016/j.agwat.2004.11.001.

53. Haroon H, Waseem A, Mahmood Q. Treatment and reuse of wastewater from beverage industry. J Chem Soc Pak. 2013;35(1):5-10.

54. Helmy M, Smith D, Selvarajoo K. Systems biology approaches integrated with artificial intelligence for optimized metabolic engineering. Metab Eng Commun. 2020;11: e00149. https://doi.org/10.1016/j.mec.2020.e00149.

55. Hernández SC, Jiménez LD, García JAB. Potential of energy production from slaughterhouse wastewater. Interciencia. 2018;43(8):558-65.

56. Hespanhol I. A inexorabilidade do reuso potável direto. Rev DAE. 2015;63(198):63-82. https://doi.org/10.4322/dae.2014.141.

57. Hsine EA, Benhammou A, Pons MN. Water resources management in soft drink industry-water use and wastewater generation. Environ Technol. 2005;26(12):1309-16. https://doi.org/10.1080/09593332608618605.

58. Huang Z, Hejazi M, Li X, Tang Q, Leng G, Liu Y, Döll P, Eisner S, Gerten D, Hanasaki N, Wada Y. Reconstruction of global gridded monthly sectoral water withdrawals for 1971-2010 and analysis of their spatiotemporal patterns. Hydrol Earth Syst Sci. 2018;22(4):2117-33. https://doi.org/10.5194/hess-22-2117-2018.

59. Institute for International and European Environmental Policy (IIEEP). Water saving potential (part 2-report). 2007. https://helvia.uco. es/bitstream/handle/10396/8756/berbel2.pdf?sequence=1. Accessed 25 May 2021.

60. IUCN. The water-food-energy nexus: discussing solutions in Nairobi. 2013. https://www.iucn.org/content/water-food-energynexus-discu ssing-solutions-nairobi.

61. Judd S. The MBR book: principles and applications of membrane bioreactors for water and wastewater treatment. Amsterdam: Elsevier; 2010.

62. Karnaningroem N, Sunaya MUL. The role of HACCP method in determining drinking water quality. In: IOP Conference series: Earth and environmental science, vol. 506. 1st ed. Bristol: IOP Publishing; 2020. p. 012031.

63. Köbnick P, Velu C, McFarlane D. Preparing for industry 4.0: Digital business model innovation in the food and beverage industry. Int J Mechatron Manuf Syst. 2020;13:59-89. https://doi.org/10.1504/IJMMS.2020.108334.

64. Koning J, Bixio D, Karabelas A, Salgot M, Schäfer A. Characterisation and assessment of water treatment technologies for reuse. Desalination. 2008;218(1-3):92-104. https://doi.org/10.1016/j.desal.2006.08.024.

65. Kupusovic T, Midzic S, Silajdzic I, Bjelavac J. Cleaner production measures in small-scale slaughterhouse industry-case study in Bosnia and Herzegovina. J Clean Prod. 2007;15(4):378-83. https://doi.org/10.1016/j.jclepro.2005.11.005.

66. Langone M, Ferrentino R, Freddi F, Andreottola G. Anaerobic digestion of blood serum water integrated in a valorization process of the bovine blood treatment. Biomass Bioenerg. 2019;120:1-8. https://doi.org/10.1016/j.biombioe.2018.10.015.

67. Legner C. Reúso de água e seus benefícios para a indústria e meio ambiente. Revista TAE. 12(II). 2013. https://www.revistatae.com.br/ Artigo/341/reuso-de-agua-e-seus-beneficios-para-a-industria-e-meio-ambiente. Accessed 06 May 2021.

68. Levine DA, Asano T. Water reclamation, recycling and reuse in industry. In: Lens P, editor. Water recycling and resource recovery in industry: Analysis, technologies and implementation. London: IWA Publishing; 2002.

69. Li G, Tang L, Zhang X, Dong J. A review of factors affecting the efficiency of clean-in-place procedures in closed processing systems. Energy. 2019;178:57-71. https://doi.org/10.1016/j.energy.2019.04.123.

70. Lines J, Kestin S. Electric stunning of trout: power reduction using a two-stagestun. Aquacult Eng. 2005;324:83-491. https://doi.org/10. 1016/j.aquaeng.2004.09.007.

71. Lu Z, Loftus S, Sha J, Wang W, Park MS, Zhang X, Hu Q. Water reuse for sustainable microalgae cultivation: current knowledge and future directions. Resour Conserv Recycl. 2020;161: 104975. https://doi.org/10.1016/j.resconrec.2020.104975.

72. Marcos AC, Al-Kassir A, Cuadros F, Yusaf T. Treatment of slaughterhouse waste water mixed with serum from lacteal industry of extremadura in Spain to produce clean energy. Energies. 2017;10(6):765. https://doi.org/10.1016/j.biombioe.2018.10.015.

73. Martí-Herrero J, Alvarez R, Flores T. Evaluation of the low technology tubular digesters in the production of biogas from slaughterhouse wastewater treatment. J Clean Prod. 2018;199:633-42. https://doi.org/10.1016/j.jclepro.2018.07.148.

74. Martin-Rios C, Hofmann A, Mackenzie N. Sustainability-oriented innovations in food waste management technology. Sustainability. 2021;13(1):210. https://doi.org/10.3390/su13010210.

75. Masi F, Rochereau J, Troesch S, Ruiz I, Soto M. Wineries wastewater treatment by constructed wetlands: a review. Water Sci Technol. 2015;71(8):1113-27. https://doi.org/10.2166/wst.2015.061.

76. Matsumura EM, Mierzwa JC. Water conservation and reuse in poultry processing plant-case study. Resour Conserv Recycl. 2008;52(6):835-42. https://doi.org/10.1016/j.resconrec.2007.10.002.

77. Mayolo-Deloisa K, González-González M, Rito-Palomares M. Laccases in food industry: bioprocessing, potential industrial and biotechnological applications. Front Bioeng Biotechnol. 2020;8:222. https://doi.org/10.3389/fbioe.2020.00222. 
78. Meneses YE, Flores RA. Feasibility, safety, and economic implications of whey-recovered water in cleaning-in-place systems: a case study on water conservation for the dairy industry. J Dairy Sci. 2016;99(5):3396-407. https://doi.org/10.3168/jds.2015-10306.

79. Milani M, Consoli S, Marzo A, Pino A, Randazzo C, Barbagallo S, Cirelli GL. Treatment of winery wastewater with a multistage constructed wetland system for irrigation reuse. Water. 2020;12(5):1260. https://doi.org/10.3390/w12051260.

80. Napoli MAS. Consumo de água na industrialização da Tilápia: estudo de caso do oeste do Paraná. 39 f. Dissertação de mestrado (Master degree). Pós-Graduação em Desenvolvimento Rural Sustentável do Centro de Ciências Agrárias da Universidade Estadual do Oeste do Paraná (Unioeste). 2015. http://tede.unioeste.br:8080/tede/handle/tede/1505. Accessed 06 May 2021.

81. Neves HC. A indústria de alimentos 4.0. Food Connect. 2021. https://doi.org/10.1590/1982-7849rac2020190097.

82. Oliveira P, Bellaver C. Balanço da água nas cadeias de aves e suínos. Agric Ind. 2009;10:39-44.

83. Ozturk E, Koseoglu H, Karaboyaci M, Yigit NO, Yetis U, Kitis M. Sustainable textile production: cleaner production assessment/ecoefficiency analysis study in a textile mill. J Clean Prod. 2016;138:248-63. https://doi.org/10.1016/j.jclepro.2016.02.071.

84. Pacheco JWF, Yamanaka HT. Guia técnico ambiental de abate (bovino e suíno)—série P + L. PeerJ. 2008. https://doi.org/10.7717/peerj. 9427.

85. Palit S. Recent advances in the application of nanotechnology in food industry and the vast vision for the future. Nanoeng Beverage Ind. 2020. https://doi.org/10.1016/B978-0-12-816677-2.00001-6.

86. Patalas-Maliszewska J, Łosyk H. An approach to assessing sustainability in the development of a manufacturing company. Sustainability. 2020;12:8787. https://doi.org/10.3390/su12218787.

87. Pervez MN, Balakrishnan M, Hasan SW, Choo KH, Zhao Y, Cai Y, Naddeo V. A critical review on nanomaterials membrane bioreactor (NMsMBR) for wastewater treatment. NPJ Clean Water. 2020;3(1):1-21. https://doi.org/10.1038/s41545-020-00090-2.

88. Rachwał K, Waśko A, Gustaw K, Polak-Berecka M. Utilization of brewery wastes in food industry. PeerJ. 2020;8: e9427. https://doi.org/10. 7717/peerj.9427.

89. Rahim R, Raman AAA. Cleaner production implementation in a fruit juice production plant. J Clean Prod. 2015;101:215-21. https://doi. org/10.1016/j.jclepro.2015.03.065.

90. Rangelov S, Nicell JA. A model of the transient kinetics of laccase-catalyzed oxidation of phenol at micromolar concentrations. Biochem Eng J. 2015;99:1-15. https://doi.org/10.1016/j.bej.2015.02.034.

91. Riera FA, Suárez A, Muro C. Nanofiltration of UHT flash cooler condensates from a dairy factory: characterisation and water reuse potential. Desalination. 2013;309:52-63. https://doi.org/10.1016/j.desal.2012.09.016.

92. RIO GRANDE DO SUL. Secretaria da Agricultura, Pecuária e Irrigação. RESOLUÇÃO DIPOA/DDA/SEAPI n 02/2016. Estabelece normas técnicas relativas às instalações e equipamentos para funcionamento de matadouros e frigoríficos de ovinos e caprinos e dá outras providências; 2016. Available in: https://www.agricultura.rs.gov.br/upload/arquivos/201608/25141014-matadouros-frigorificos-deovinos-ecaprinos.pdf. Accessed 15 Dec 2021.

93. Risku-Norja H, Mäenpää I. MFA model to assess economic and environmental consequences of food production and consumption. Ecol Econ. 2007;60(4):700-11. https://doi.org/10.1016/j.ecolecon.2006.05.001.

94. Rodriguez-Sanchez C, Sellers-Rubio R. Sustainability in the beverage industry: a research agenda from the demand side. Sustainability. 2021;13(1):186. https://doi.org/10.3390/su13010186.

95. Santos KA, Gomes TM, Rossi F, Kushida MM, Del Bianchi VL, Ribeiro R, Tommaso G. Water reuse: dairy effluent treated by a hybrid anaerobic biofilm baffled reactor and its application in lettuce irrigation. Water Supply. 2020. https://doi.org/10.2166/ws.2020.276.

96. Sipper B. It is time for glass again: can we end beverage industry's use of plastic? Water Advantage. 2019. https://wasteadvantagemag. com/its-time-for-glass-again-can-we-end-beverage-industrys-use-of-plastic/. Accessed 06 May 2021.

97. Souza FKB, Paradela LJF, Pizarro JV. Perícia ambiental de um matadouro da região nordeste do Estado do Pará. Amazôn Foco. 2013;1:198-219.

98. Talaviya T, Shah D, Patel N, Yagnik H, Shah M. Implementation of artificial intelligence in agriculture for optimisation of irrigation and application of pesticides and herbicides. Artif Intell Agric. 2020;4:58-73. https://doi.org/10.1016/j.aiia.2020.04.002.

99. Tekerlekopoulou AG, Economou CN, Tatoulis TI, Akratos CS, Vayenas DV. Wastewater treatment and water reuse in the food industry. Interact Food Ind Environ. 2020. https://doi.org/10.1016/B978-0-12-816449-5.00008-4.

100. Torres TL, de Oliveira JC, Baum CA, Becegato VA, Henkes JA. Gestão do uso da água na indústria: aplicação do reuso e recuperação. Rev Gest Sust Ambient. 2018;7(2):370-85. https://doi.org/10.19177/rgsa.v7e22018370-385.

101. Theobald D. Challenges and trends in food industry water management. Water technology. 2017. https://www.watertechonline.com/ food-industry-water-management/. Accessed 06 May 2021.

102. Thompson M. Port Macquarie's urban reclaimed water supply scheme. New South Wales: Proceedings IPWEA NSW Division Annual Conference; 2005.

103. Thompson J, Mitcham E, Mitchell G. Preparation for fresh market. In: Kader AA, editor. Postharvest technology of horticultural crops. Berkeley: University of California, Division of Agriculture and Natural Resources; 2002. p. 67-79.

104. Toussaint M, Cabanelas P, González-Alvarado TE. What about the consumer choice? The influence of social sustainability on consumer's purchasing behavior in the Food Value Chain. Eur Res Manag Bus Econ. 2021;27(1): 100134. https://doi.org/10.1016/j.iedeen.2020.100134.

105. TSI (Turkish Statistical Institute). Manufacturing industry water indicators. Ankara: TSI; 2010.

106. UNEP. Cleaner production assessment in meat processing. Dinamarca: UNEP; 2000. p. 83. http://www.unep.fr/shared/publications/pdf/ 2482-CPmeat.pdf.

107. Unfried LC, Yoshi CVH. Sustentabilidade no abate e processamento de aves. FACESI Rev. 2012;4(4):1-4. https://docplayer.com.br/14379 729-Sustentabilidade-no-abate-e-processamento-de-aves.html.

108. Urase T. Improvement of membrane bioreactor operations for color and oil removal from wastewater. Doctoral dissertation. Japan: Tokyo University of Technology; 2016.

109. U.S. EPA. National primary drinking water regulations. 40 CFR Part 141. Washington: United States-Environmental Protection Agency; 2002. p. 436-8. https://www.epa.gov/ground-water-and-drinking-water/national-primary-drinking-water-regulations.

110. U.S. EPA. Guidelines for water reuse. Washington: United States-Environmental Protection Agency; 2004. https://cfpub.epa.gov/si/si_ public_record_report.cfm?Lab=NRMRL\&dirEntryld=129543. 
111. Environmental Tecnology Best Practice Programme. Reducing water and effluent costs in red meat abattoirs. Good practice guideGG234. UK: Environmental Tecnology Best Practice Programme; 2000.

112. Vaidya S, Ambad P, Bhosle S. Industry 4.0-a glimpse. Procedia Manuf. 2018;20:233-8. https://doi.org/10.1016/j.promfg.2018.02.034.

113. Valta K, Moustakas K, Sotiropoulos A, Malamis D, Haralambous KJ. Adaptation measures for the food and beverage industry to the impact of climate change on water availability. Desalin Water Treat. 2016;57(5):2336-43. https://doi.org/10.1080/19443994.2015.1049407.

114. Valta K, Kosanovic T, Malamis D, Moustakas K, Loizidou M. Overview of water usage and wastewater management in the food and beverage industry. Desalin Water Treat. 2015;53(12):3335-47. https://doi.org/10.1080/19443994.2014.934100.

115. Vourch M, Balannec B, Chaufer B, Dorange G. Treatment of dairy industry wastewater by reverse osmosis for water reuse. Desalination. 2008;219(1-3):190-202. https://doi.org/10.1016/j.desal.2007.05.013.

116. Yazdani M, Ebrahimi-Nik M, Heidari A, Abbaspour-Fard MH. Improvement of biogas production from slaughterhouse wastewater using biosynthesized iron nanoparticles from water treatment sludge. Renew Energy. 2019;135:496-501. https://doi.org/10.1016/j.renene. 2018.12.019.

117. Wang S, Hawkins GL, Kiepper BH, Das KC. Treatment of slaughterhouse blood waste using pilot scale two-stage anaerobic digesters for biogas production. Renew Energy. 2018;126:552-62. https://doi.org/10.1016/j.renene.2018.03.076.

118. WHO (World Health Organization). Guidelines for the safe use of wastewater, excreta and greywater. Washington: WHO; 2006.

119. WHO. Disinfection. In: WHO seminar pack for drinking water quality. Geneva: World Health Organization; 1997.

120. WRAP (Waste \& Resources Action Programme). Water minimisation in the food and drink industry-business resource efficiency guide. Banbury: WRAP; 2013.

Publisher's Note Springer Nature remains neutral with regard to jurisdictional claims in published maps and institutional affiliations. 